\author{
B. HAMAR ZSIDEKOVÁ, G. BÁLINT, \\ B. GAUZER
}

\title{
AN ANALYSIS OF REGIONAL SNOW ASSESSMENTS AT SELECTED HYDROLOGICAL STATIONS ON THE DANUBE AND TISZA RIVERS
}

\section{ABSTRACT}

Precipitation falling on a land surface is one of the most important elements of the hydrological cycle, and it is the only input term of the water balance on the Earth's surface. On those areas of the Earth where a part of the annual precipitation falls in the form of snow, the rhythm of the hydrological cycle, i.e., the water balance within a year, follows a pattern that deviates from that of the precipitation record. Precipitation falling in a solid state enters the hydrological cycle with a time lag that might be as much as several months after the precipitation event. Therefore, instead of considering the observed values of precipitation when describing the various elements of the hydrological cycle, it is more expedient to take the surface water input into account. This is a fraction of the precipitation which is present on the land surface in a liquid state. Consequently, the most important task of the various snow models within the rainfall - runoff and water budget schemes is to transform the precipitation values observed into surface water input values. Spring time runoff largely depends on the snowmelt component, and it gives the possibility of estimating the expected seasonal volume of the flow and flood peaks. Seasonal forecasts based on the relationship between snow resources and expected precipitation during the spring months have been analyzed for the Danube and Tisza rivers.
\end{abstract}

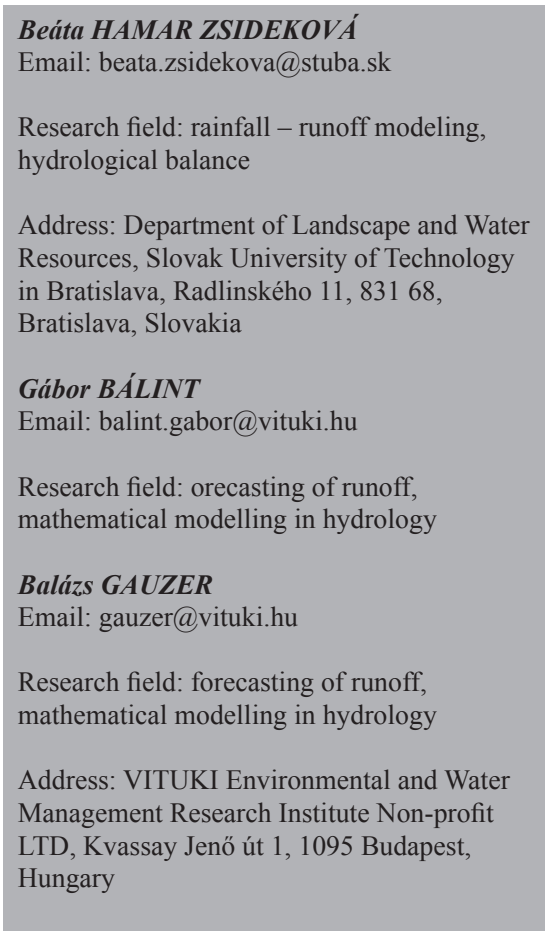

\section{KEY WORDS}

- HOLV snowmelt model,

- early warning.

- spring floods.

\section{INTRODUCTION}

The accurate estimation of the volume of water stored in a snow pack and its rate of release is essential for predicting the flows during the snowmelt period. The information on snow cover depth and its water equivalent is a pre-requisite for estimating the snowmelt. In the mountainous regions little information relating to the meteorological and physical factors affecting runoff is available. Snowmelt is typically not measured quantitatively but must be estimated (Clark et al. 2009). The factors involved in the computation of snowmelt are so numerous that it is practically impossible to account for all of them. Some of them are not regularly measured or are available only on 
Vol. XXI, 2013, No. 3, $43-56$

experimental sites. An important variable in mountainous watersheds during the snowmelt season is the aerial extent of the snow cover.

\section{ASSESSMENT OF SNOW RESOURCES}

The HOLV snowmelt model has been developed by the Hungarian National Hydrological Forecasting Service (VITUKI OVSZ/ NHFS). The model originates from the early 1980s (Bálint, G. \& Bartha, P., 1982), and it is under continuous development (Bálint, G. \& Gauzer, B., 1994). Its distributed version over a grid with a 0.1 degree of resolution is currently in use for assessing snow accumulation and ablation. The snowmelt model has a flexible structure; it is able to change its own structure as a function of the availability of the data. In cases when only precipitation and air temperature data are available, the temperature index method is used. When other data are also accessible (cloudiness, dew point, wind speed), the use of an energy balance model is preferred. If there are suitable data available for calculating the energy terms, the energy balance method can be applied. These simulations appear to provide an adequate representation of snow climatology. While the use of more physically-based energy balance methods may help to improve the simulations (Slater et al., 2001; Etchevers et al., 2004), such methods have larger data requirements, and it is unclear whether the improvements so obtained would be significant, given the uncertainty in the model input data. Otherwise, the degree-day or temperature index method can be used. The temperature index is considered time-variable, as a consequence of seasonal changes in the solar radiation values corresponding to the same air temperatures, and even of changes of the albedo of the snow surface. The calculations need to be carried out with a daily time step. Since the application presumes conditions free of snow when started, it is proper to begin the calculations at the time of the year when the catchments are covered with a minimum quantity of snow. It can be run every day after receiving the morning datasets and calculates all the values for the last 24 hours.

\subsection{Application of energy balance and temperature index approaches}

The energy balance of a snow cover:

$$
\mathrm{E}_{\mathrm{o}}-\mathrm{E}_{\mathrm{z}}=(1-\mathrm{A}) \mathrm{E}_{\mathrm{sw}}+\mathrm{E}_{\mathrm{lw}}-\mathrm{E}_{\mathrm{e}}+\mathrm{E}_{\mathrm{s}}+\mathrm{E}_{1}+\mathrm{E}_{\mathrm{c}}+\mathrm{E}_{\mathrm{g}}
$$

where:

E - the total energy absorbed/emitted by the snow surface $[\mathrm{J} /$ $\left.\mathrm{m}^{2} \mathrm{~s}\right]$,

$\mathrm{E}_{\mathrm{z}}$ - the total flux of the energy across the boundary between the snow and soil $\left[\mathrm{J} / \mathrm{m}^{2} \mathrm{~s}\right]$,

$\mathrm{E}_{\mathrm{sw}}$ - the energy arriving onto the snow surface from shortwave radiation $\left[\mathrm{J} / \mathrm{m}^{2} \mathrm{~s}\right]$,

A - the albedo of the snow, which expresses the fraction of the incoming short-wave radiation, which will be reflected by the snow's surface back to the atmosphere $\left[\mathrm{J} / \mathrm{m}^{2} \mathrm{~s}\right]$.
$\mathrm{E}_{\mathrm{lw}}$ - the atmospheric long-wave radiation $\left[\mathrm{J} / \mathrm{m}^{2} \mathrm{~s}\right]$

$\mathrm{E}_{\mathrm{e}}$ - the radiation emitted by the snow's surface $\left[\mathrm{J} / \mathrm{m}^{2} \mathrm{~s}\right]$,

$\mathrm{E}_{\mathrm{s}}$ - the sensible heat flux, caused by the difference in temperature between the snow's surface and the atmosphere above the snow $\left[\mathrm{J} / \mathrm{m}^{2} \mathrm{~s}\right]$,

$\mathrm{E}_{1}$ - the latent heat flux, caused by the difference in vapour pressure on the snow's surface and the atmosphere above the snow $\left[\mathrm{J} / \mathrm{m}^{2} \mathrm{~s}\right]$,

$E_{c}-$ the energy brought to the snow's surface by rainfall $\left[\mathrm{J} / \mathrm{m}^{2} \mathrm{~s}\right]$.

In practical cases the changes in the energy of the snow cover is expressed in terms of meltwater millimetres instead of energy units. If there are data available for calculating the energy terms on the right-hand side of Eq.(1), an energy balance method can be applied. In the most practical cases these terms cannot be computed with an acceptable degree of accuracy. In these cases the temperature index method can be used.

The basic equation of the temperature index method is:

$$
E_{o}-E_{z}=M=\left(C_{o}+C_{p} P\right)\left(T-T_{o}\right)
$$

where:

M - the quantity of water melted/refroze during the selected period of time $[\mathrm{mm}]$,

$\mathrm{C}_{\mathrm{o}}$ - the temperature index $\left[\mathrm{mm}^{\circ} \mathrm{C}^{-1}\right]$,

$\mathrm{C}_{\mathrm{p}}$ - coefficient for taking into account the effect of precipitation $\left[{ }^{\circ} \mathrm{C}^{-1}\right]$,

$\mathrm{P}$ - the precipitation $[\mathrm{mm}]$,

$\mathrm{T}$ - the air temperature $\left[{ }^{\circ} \mathrm{C}\right]$,

$\mathrm{T}_{\mathrm{o}}-$ the threshold air temperature $\left[{ }^{\circ} \mathrm{C}\right]$.

The temperature index is considered time-variable, as a consequence of seasonal changes in the solar radiation values corresponding to the same air temperature, and even of changes in the albedo of the snow's surface.

When the precipitation falls in the form of snow, the precipitation observation data are to be corrected as a function of the wind speed, with the following formula:

$$
\begin{gathered}
\mathrm{P}=\mathrm{P}_{\mathrm{o}} \mathrm{C} ; \\
\mathrm{C}=1.0+(\mathrm{u}-1.0) \mathrm{S}_{\mathrm{c}}
\end{gathered}
$$

where:

$\mathrm{P}-$ the corrected value of the precipitation [mm],

$\mathrm{P}_{\mathrm{o}}-$ the observed value of the precipitation [mm],

$\mathrm{C}$ - the calculated correction coefficient,

$\mathrm{U}$ - wind speed $\left[\mathrm{m}^{3} / \mathrm{s}\right]$,

$\mathrm{S}_{\mathrm{c}}-$ the correction factor.

The compression of the snow cover is calculated as follows:

$$
\rho_{\mathrm{h}, \mathrm{i}}=\rho_{\mathrm{hmax}}\left(1-\mathrm{e}^{-\mathrm{k} \Delta t}\right) \rho_{\mathrm{h}, \mathrm{i}-\mathrm{e}} \mathrm{e}^{-\mathrm{k} \Delta \mathrm{t}}
$$


where:

$\rho_{\mathrm{h}, \mathrm{i}-1}-$ the density of the snow cover in the (i-1)-th time step [gr/ $\mathrm{cm}^{3}$,

$\rho_{\mathrm{h}, \mathrm{i}}$ - the density of the snow cover in the i-th time step [gr/ $\left.\mathrm{cm}^{3}\right]$,

$\rho_{\text {hmax }}$ - the maximum density obtained of the snow cover $\left[\mathrm{gr} / \mathrm{cm}^{3}\right]$,

$\Delta \mathrm{t}$ - the time step,

$\mathrm{k} \quad-$ the rate of compression of the snow cover.

The intensity of the infiltration of effective precipitation into the soil, and thus the time variation of the rate of infiltration, basically depends on the frozen or unfrozen state of the soil and the depth of the soil frost. Consequently, a snow model can supply acceptable input to a precipitation-runoff model when it is able to provide information about soil frost too. This process was accounted for in our model with the following expression:

$$
\mathrm{TF}_{\mathrm{i}}=\mathrm{TF}_{\mathrm{i}-1} \mathrm{TFD}_{\mathrm{H}}-\alpha_{\mathrm{TF}} \mathrm{T}_{1}
$$

where:

$\mathrm{TF}_{\mathrm{i}}$ - the depth of the soil frost in the i-th time step [cm],

$\mathrm{TF}_{\mathrm{i}-1}$ - the depth of the soil frost in the (i-1)-th time step [cm],

$\mathrm{TFD}_{\mathrm{H}}$ - the soil frost reduction coefficient corresponding to snow depth $\mathrm{H}$,

$\alpha_{\mathrm{TF}} \quad$ - the coefficient of the soil frost $\left[\mathrm{cm} /{ }^{\circ} \mathrm{C}\right]$,

$\mathrm{T}_{1} \quad$ - the mean air temperature $\left[{ }^{\circ} \mathrm{C}\right]$.

\subsection{Calculation of the energy terms}

The short wave radiation can be calculated by the following formula:

$$
\begin{array}{cl}
\mathrm{E}_{\mathrm{sw}}=\mathrm{E}\left(\mathrm{a}_{\mathrm{sw}}+\mathrm{b}_{\mathrm{sw}} \mathrm{N}_{\mathrm{f}}\right) \\
\begin{array}{cc}
\text { where: } & \text { (7) } \\
\mathrm{E}_{\mathrm{sw}} & - \text { the short wave radiation arriving onto the snow surface } \\
\left.\mathrm{E} \quad \mathrm{J} / \mathrm{m}^{2} \mathrm{~s}\right], & - \text { the maximum possible radiation depending on the ge- } \\
& \text { ographical altitude and on the season }\left[\mathrm{J} / \mathrm{m}^{2} \mathrm{~s}\right],
\end{array} \\
\mathrm{N}_{\mathrm{f}} \quad \begin{array}{c}
\text { fraction of the sky covered by clouds expressed as } \\
\text { a decimal fraction, }
\end{array} \\
\mathrm{a}_{\mathrm{sw}}, \mathrm{b}_{\mathrm{sw}} \quad-\text { empirical constants. }
\end{array}
$$

In the case of a temporary lack of data, cloudiness is approximated as a function of the daily temperature fluctuations with the following formula:

$$
\mathrm{N}_{\mathrm{f}}=\mathrm{a}_{\mathrm{f}}+\mathrm{b}_{\mathrm{f}}\left(\mathrm{T}_{\max }-\mathrm{T}_{\min }\right)
$$

Where $\mathrm{T}_{\max }$ and $\mathrm{T}_{\min }$ are the daily maximum and minimum air temperatures, respectively, and $a_{f}, b_{f}$ are the empirical constants.

The albedo of the snow cover is mostly affected by the crystalline structure of the snow, the latter of which changes as a function of the melting process. The crystalline structure of the melting snow will be completely restructured, and this new structure remains unchanged after refreezing.

This process is described as follows:

where:

$$
\mathrm{A}_{\mathrm{i}}=\mathrm{A}_{\mathrm{o}} \mathrm{e}^{-\mathrm{k} a v \tau} ; \quad \tau=\Sigma \mathrm{T}_{\max }
$$

A - albedo of the snowcover in the i-th time step,

$\mathrm{A}_{\mathrm{o}}$ - the maximal albedo value of newly fallen snow,

$\tau$ - the sum of the maximum positive temperature values observed since the last snowfall $\left[{ }^{\circ} \mathrm{C}\right]$,

$\mathrm{k}_{\mathrm{a}}$ - empirical constant.

The atmospheric radiation is calculated by the Stephan-Bolzmann law in the form of:

where:

$$
\mathrm{E}_{\mathrm{lw}}=\varepsilon_{\mathrm{a}} \sigma \mathrm{T}_{1}^{4}
$$

$\mathrm{E}_{\mathrm{lw}}$ - the atmospheric radiation $\left[\mathrm{J} / \mathrm{m}^{2} \mathrm{~s}\right]$,

$\varepsilon_{\mathrm{a}}$ - the radiation coefficient of the atmosphere,

$\sigma \quad$ the Stephan-Boltzmann constant $\left(5.73510^{-8} \mathrm{~J} / \mathrm{m}^{2} \mathrm{~K}^{2} \mathrm{~s}^{2}\right)$,

$\mathrm{T}_{1}-$ the absolute temperature of the emitting object $\left[{ }^{\circ} \mathrm{K}\right]$.

The Brundt equation for calculating $\varepsilon_{\mathrm{a}}$ :

$$
\varepsilon_{\mathrm{a}}=\left(\mathrm{a}_{\mathrm{lw}}+\mathrm{b}_{1 \mathrm{w}} \sqrt{\mathrm{e}}\right)
$$

where:

e - the vapour pressure of the atmosphere [mbar]

$\mathrm{a}_{\mathrm{lw}}, \mathrm{b}_{\mathrm{lw}}-$ empirical constants

The value of the vapour pressure of the atmosphere can be calculated from the value of the dew point. In the case of a temporary lack of data, the dew point can be estimated by the daily minimal air temperature.

Atmospheric radiation becomes more intensive when the sky is cloudy, since clouds also emit radiation. This effect can be taken into account by modifying the radiation coefficient:

$$
\varepsilon_{\mathrm{a}}=\varepsilon_{\mathrm{a}}\left(1+0.24 \mathrm{~N}_{\mathrm{f}}\right)
$$

To carry out the calculations, knowledge of the temperature of the emitting object is also needed. This is given by the following relationship:

where:

$$
\mathrm{T}_{1}=\mathrm{T}_{\mathrm{a}}+0.1\left(\mathrm{~N}_{\mathrm{f}} \Delta \mathrm{T}\right)
$$

$\mathrm{T}_{1}$ - the temperature of the emitting object (clouds) $\left[{ }^{\circ} \mathrm{C}\right]$,

$\mathrm{T}_{-}$- the air temperature $\left[{ }^{\circ} \mathrm{C}\right]$,

$\Delta \mathrm{T}$ - the difference between the cloud temperature and air temperature $\left[{ }^{\circ} \mathrm{C}\right]$.

Earth radiation can be calculated by the Stephan-Bolzmann law too. The temperature of the snow surface can be considered as that of the air temperature during the day, and the dew point during the night. 
The sensible heat flux is usually calculated with the following expression:

$$
\mathrm{E}_{\mathrm{s}}=\mathrm{D}_{\mathrm{s}} \mathrm{u}\left(\mathrm{T}_{\mathrm{h}}-\mathrm{T}_{\mathrm{o}}\right)
$$

where:

$E_{e}$ - the sensible heat flux $\left[\mathrm{J} / \mathrm{m}^{2} \mathrm{~s}\right]$,

$D_{s}$ - the coefficient of the energy exchange $\left[\mathrm{J} / \mathrm{m}^{2 \circ} \mathrm{C}\right]$

$\mathrm{u}$ - the speed of the wind at $\mathrm{h} \mathrm{m}$ above the snow surface $[\mathrm{m} / \mathrm{s}]$,

$\mathrm{T}_{\mathrm{h}}$ - the air temperature at $\mathrm{h} \mathrm{m}$ above the snow surface $\left[{ }^{\circ} \mathrm{C}\right]$,

$\mathrm{T}_{\mathrm{o}}$ - the temperature of the snow surface $\left[{ }^{\circ} \mathrm{C}\right]$.

The latent heat flux is described as:

where:

$$
\mathrm{E}_{1}=\mathrm{D}_{1} \mathrm{u}\left(\mathrm{e}_{\mathrm{h}}-\mathrm{e}_{\mathrm{o}}\right)
$$

$\mathrm{E}_{1}$ - the latent heat flux $\left[\mathrm{J} / \mathrm{m}^{2} \mathrm{~s}\right]$,

$\mathrm{D}_{1}-$ the coefficient of the energy exchange $\left[\mathrm{J} / \mathrm{m}^{2 \circ} \mathrm{C}\right]$,

$\mathrm{u}$ - the speed of wind at $\mathrm{h} \mathrm{m}$ above the snow surface $[\mathrm{m} / \mathrm{s}]$,

$\mathrm{e}_{\mathrm{h}}$ - the atmospheric vapor pressure at $\mathrm{h}$ meter above the snow surface [mbar],

$e_{o}-$ the vapor pressure of the atmosphere at the snow surface [mbar],

The energy provided by rainfall can be described as:

$$
\mathrm{E}_{\mathrm{c}}=4210 \mathrm{~T}_{\mathrm{p}} \mathrm{P}
$$

where:

$E_{c}$ - the energy input via rainfall into the snow cover $\left[\mathrm{J} / \mathrm{m}^{2} \mathrm{~s}\right]$,

$\mathrm{T}_{\mathrm{p}}$ - the temperature of the rain $\left[{ }^{\circ} \mathrm{C}\right]$,

$\mathrm{P}-$ the rainfall intensity $[\mathrm{mm} / \mathrm{s}]$.

The temperature of rain can be approximated by that of the air.

The problem of identifying the model's structure and estimating the model parameters is clearly still unresolved as was declared in a similar study (Clark et al. 2009): The lack of data for evaluating a model is a ubiquitous problem in hydrology, and there is increasing recognition of the need to compare model output to multiple quantitative and qualitative data sources (e.g., Gupta et al., 1998). Indeed, there is an emerging research trend to creatively use all the available data in such a way that the data provides information on both the behaviour of a model's sub-components and the appropriate values for the individual model parameters (e.g., Gupta et al., 2008). For example, qualitative information on snow cover duration across the Alpine-Carpathian region can provide more information on the appropriate values of melt parameters than quantitative data on the snow water equivalent at a single station location. Further efforts in improving snow models, i.e., diagnosing and correcting model weaknesses or regionalizing model parameter sets, will require the creative assessment of a much broader set of information than the statistics on seasonal snow climatology considered in this paper. Important data sources for future studies will be both satellite data on snow-covered areas (e.g., as produced by Sirguey et al., 2009, as a preliminary analysis, which indicates that standard satellite snow products have problems with snow-cloud discrimination) and seasonal and diurnal cycles in streamflows.

\section{SNOW-COVERED AREA ON THE DANUBE RIVER BASIN}

Among the objectives of these studies, the possible use of satellite information for calculating snow water equivalents was included. A temporal evaluation of snow cover over large areas can be successfully observed using different satellite images.

The quality of calculating snow-related processes (such as snow accumulation, snow melting) might be improved by the application of satellite images. There are different remote sensing datasets of snow cover available, which include data from optical and microwave sensors. The advantage of microwave sensors is that they penetrate through clouds and allow for the estimating of snow water equivalents, but still have rather coarse spatial resolutions and relatively low mapping accuracy in mountainous regions. The advantage of optical products (e.g., MODIS) is attractive spatial and temporal resolutions and large snow cover mapping accuracy for cloud-free conditions, but the limitation are clouds. The main sources of uncertainties are:

- satellite information is available only for cloud-free areas,

- satellite information provide data on snow coverage but without any information on the quantity of the snow water equivalent.

Theoretically, the accuracy of snow simulations can be improved by optimally combining model outputs with observations. This can be done by assimilating point snow water equivalent observations and satellite-derived estimates of snow-covered areas into the model (Clark et al., 2009; Slater and Clark, 2006). Data assimilation will provide snow information that takes advantage of the relative strengths of the data and models, and the merged data-model product will be of greater accuracy than either the data or model alone. However, data assimilation will only improve present-day simulations, and there is a need to identify appropriate parameter sets that can be used for future scenarios, for example, to simulate the impact of climate change on water resources.

\subsection{Description of the studied region}

The Danube is the second greatest river in Europe after the Volga. The Danube River basin is situated in Central and Eastern Europe. The Danube River Basin is Europe's second largest river basin, with a total area of $801,463 \mathrm{~km}^{2}$. It is the world's most international river basin as it includes the territories of 19 countries. The ecosystems of the Danube River Basin are highly valuable in environmental, economic, historical and social terms, but they are subject to increasing pressure and serious pollution from agriculture, industry and cities. The Danube River Basin can - based on its 


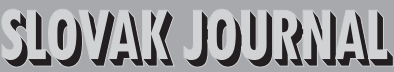

Vol. XXI, 2013, No. 3, $43-56$

gradients - be divided into three sub-regions: the upper basin, the middle basin, and the lower basin (including the Danube Delta) The Upper Basin extends from the source of the Danube in Germany to Bratislava in Slovakia. The Middle Basin is the largest of the three sub-regions, extending from Bratislava to the dams of the Iron Gate Gorge on the border between Serbia and Romania. The Danube connects with 27 large and over 300 small tributaries on its way from the Black Forest to the Black Sea. There are also a large number of lakes in the Danube Basin. The Tisza is the longest tributary of the Danube and the largest by catchment area. At $966 \mathrm{~km}$ in length, it is the second largest by flow after the Sava River. It drains an area of $157,186 \mathrm{~km}^{2}$ in five countries (Slovakia, Ukraine, Hungary, Romania and Serbia).

Relative to the Danube Basin a very relevant study was carried out by Parajka and Blöschl (2006) to evaluate the Moderate Resolution Imaging Spectroradiometer (MODIS) snow cover product over the territory of Austria. The aims of the referred study were (a) to analyse the spatial and temporal variability of the MODIS snow product classes, (b) to examine the accuracy of the MODIS snow product against in situ snow depth data, and (c) to identify the main factors that may influence the accuracy of the MODIS classification. The authors used daily MODIS grid maps (version 4) and daily snow depth measurements at a dense network of climate stations. The results indicated that, on average, clouds obscured $63 \%$ of Austria, which significantly restricted the applicability of the MODIS snow cover images to hydrological modelling. It was also noted that on cloud-free days, however, the classification accuracy is very good with an average of $95 \%$. There is no consistent relationship between the classification errors, dominant land cover type and local topographical variability, but there are clear seasonal patterns to the errors. In December and January, the errors are around 15\%, while in the warm months, they are less than $1 \%$. This seasonal pattern is related to the overall percentage of snow cover, although in the spring, when there is a well-developed snow pack, errors tend to be smaller than they are in the early winter for the same overall percentage of snow cover. Overestimation and underestimation errors balance during most of the year, which indicates little bias. The comparison made in the Austrian study of daily air temperature maps with MODIS snow cover images indicated that almost all MODIS overestimation errors are caused by the misclassification of cirrus clouds as snow.

Even though the MODIS snow product analysed was based on a liberal cloud mask and an improved cloud detection algorithm (Riggs and Hall, 2002), the average cloud cover is 63\%. This is very likely due to the climate conditions over the Alps rather than an artefact of the algorithm (Parajka and Blöschl 2006, Parajka et al. 2012). This large cloud cover percentage has significant implications for the application of the MODIS snow product. Overall, the inaccuracy of the method for calculating snow water equivalents using satellite information can be unacceptably high.

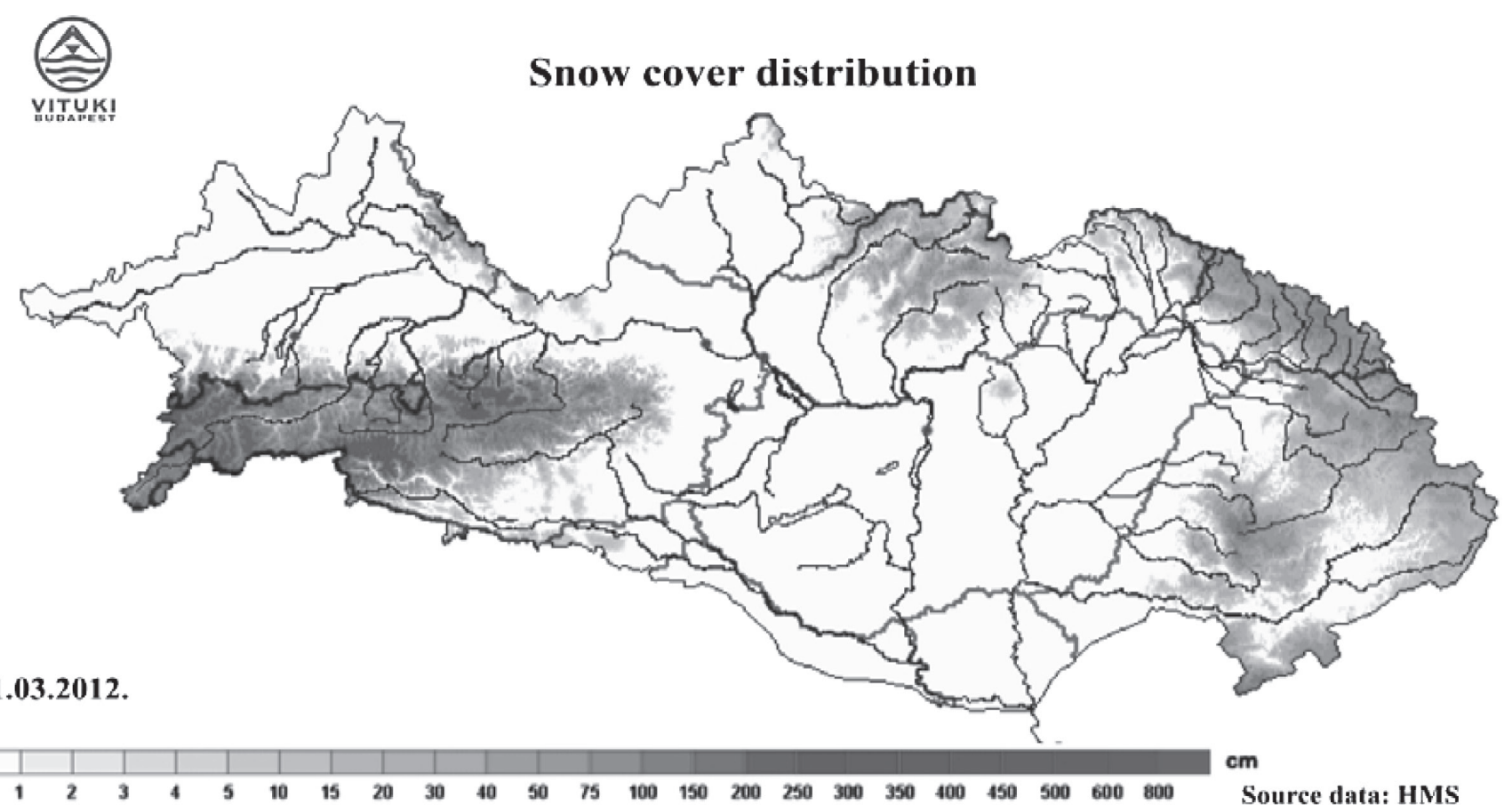

Fig. 1 Snow depths in the Upper-Central Danube region 11.3.2012 (VITUKI). 


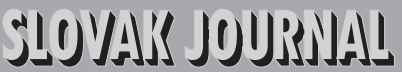
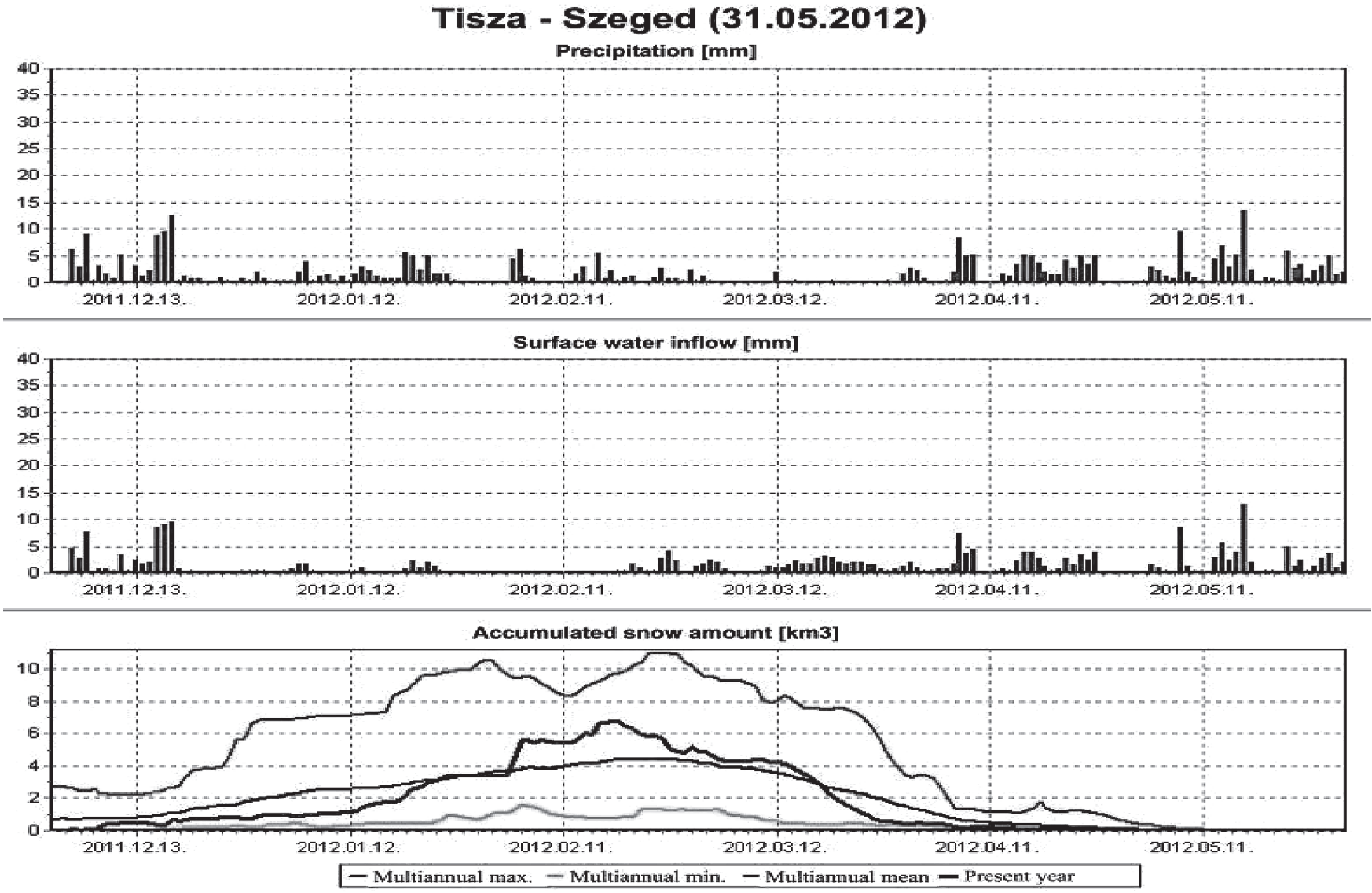

Fig. 2 Water budget of the snow pack in the Tisza-Szeged River basin.

\section{EARLY WARNING OF SPRING FLOODS}

Although floods can come at any time, in the late winter and early spring, when we have snow, frozen ground and no leaves on the trees in deciduous forests, they all increase the possibility of flood formation. Ice phenomena sometimes make the situation even more dangerous when ice jams result in extensive inundations, even at relatively moderate flow rates when the return period of the flood peak (in terms of discharges) is short. Rain during snow events can be the most dangerous hydrological events in many sub-basins of the Danube Basin.

The accurate estimation of the volume of water stored in a snow pack and its rate of release is essential for predicting the flow during a long snowmelt period. Owing to the distinct elevation distribution of watersheds, the snowmelt-affected period is long, while different parts of the mountain ranges produce snowmelt-induced runoff. An important variable in the mountainous watersheds during the snowmelt season is the aerial extent of the snow cover. The water equivalent in the snow pack over a large area is the main factor defining the volume of runoff during spring months. Snow accumulation and ablation processes may go on in certain elevation zones and, at the same time, the rainfall - induced component becomes more significant as the rise in air temperature consumes snow resources at lower elevations.

The overall seasonal pattern shows that the maximum of snow resources is usually reached in the Carpathian Dinari regions from the end of February till mid-March. The Alpine part of the Danube Basin is characterised by the maximum of overall snow resources in mid-March to early April. The snow resources are only the first prerequisite to predict expected seasonal runoff and flood peaks, and together with those, indicate the danger of possible flooding.

Simple linear regression types of relationships were designed to calculate monthly runoff and monthly maximum water levels as a function of the snow resources, as well as anomalies of the monthly volumes of precipitation (rainfall and snow) and that of air temperatures. In that there are no reliable long - term forecasts of precipitation and air temperature available, climatic means can be taken into consideration with the indication of standard deviations producing lower and higher estimates.

The application of the described scheme using March $1^{\text {st }}$ estimates of snow resources produced long-term predictions of the 


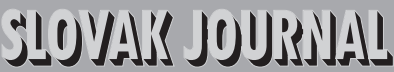 \\ 1) 5

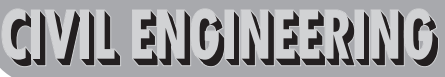

Vol. XXI, 2013, No. 3, $43-56$

monthly flow volume for the Danube-Budapest and Tisza-Szeged (Figures 3-4) for the last two decades. Instead of the climatic values, seasonal predictions of precipitation and air temperatures issued by the Hungarian Meteorological Service were used. Spring time runoff largely depends on the snowmelt component, and it gives the possibility of estimating the expected seasonal volume of flow and flood peaks. Seasonal forecasts based on the relationship between snow resources and expected precipitation during spring months have been analysed for the Danube and Tisza rivers.

Low March estimates of monthly runoff on the Danube at Budapest were more or less followed by low observed values during most of the 1990s. The expected higher values for the years 2006-2010 were not proved by observations, and the flow passing the Budapest cross section remained around or even below the
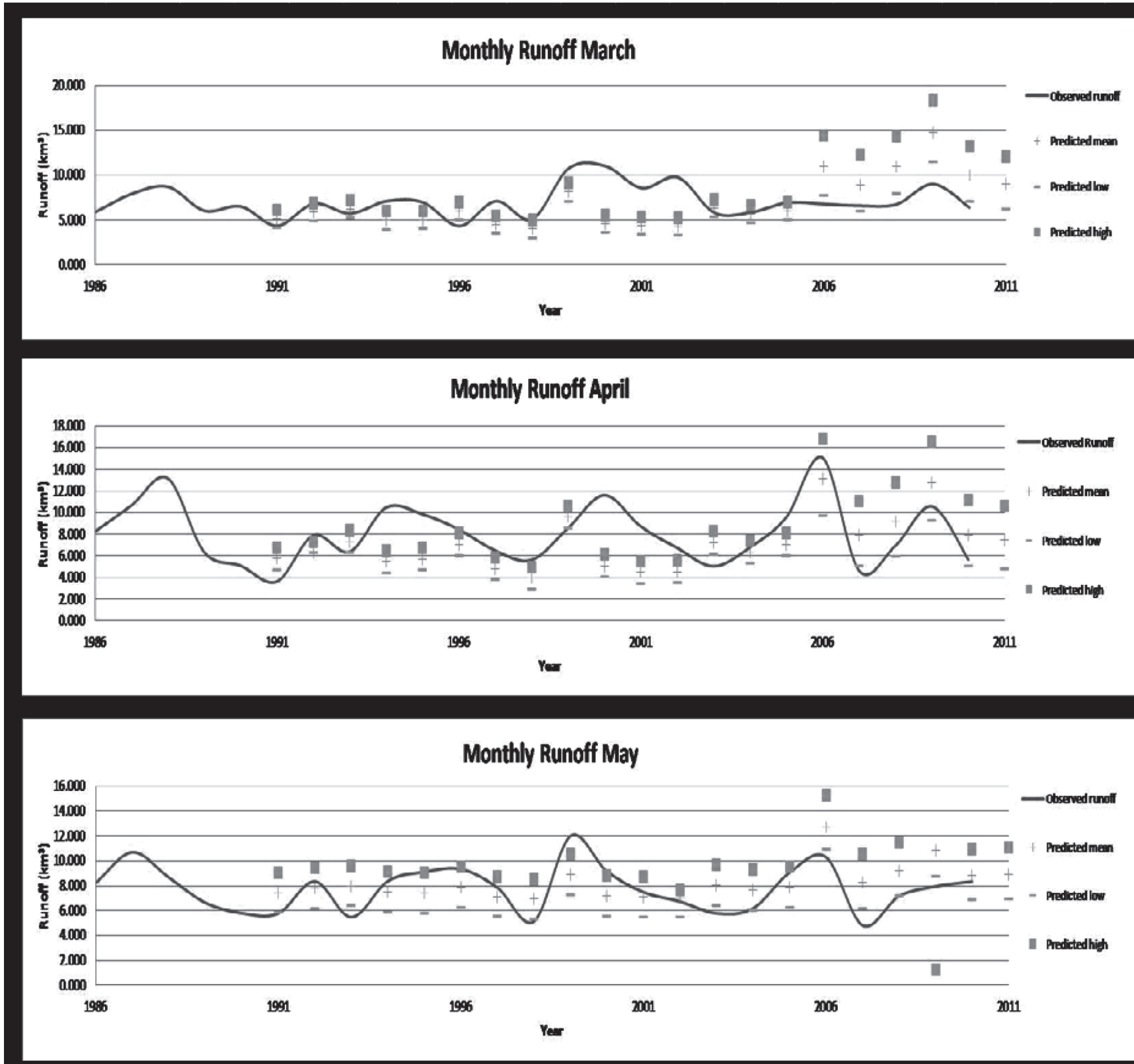

Fig. 3 Predicted and observed monthly runoff for the Danube at Budapest. 


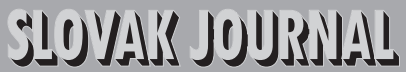 \\ 1) $\vec{s}$

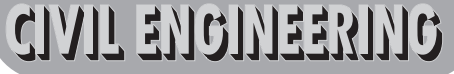

Vol. XXI, 2013, No. 3, $43-56$

lower estimates. April values were underestimated in the 1990s but higher values captured after 2006. Higher May volumes of observed runoff remained within the predicted range during the 1990s, but the predictions mostly failed after 2006 (Fig.3). The Tisza-Szeged monthly runoff predictions were relatively successful in March, and most of the estimates remained within the predicted range; however, the high value of 2001 was not captured. Less predictive skill was proved for April, while May was a complete failure with almost all of the observed values outside the predicted range (Fig.4).

The relation between spring time runoff, monthly values and the peak flow were utilised to make estimates of the monthly maximum

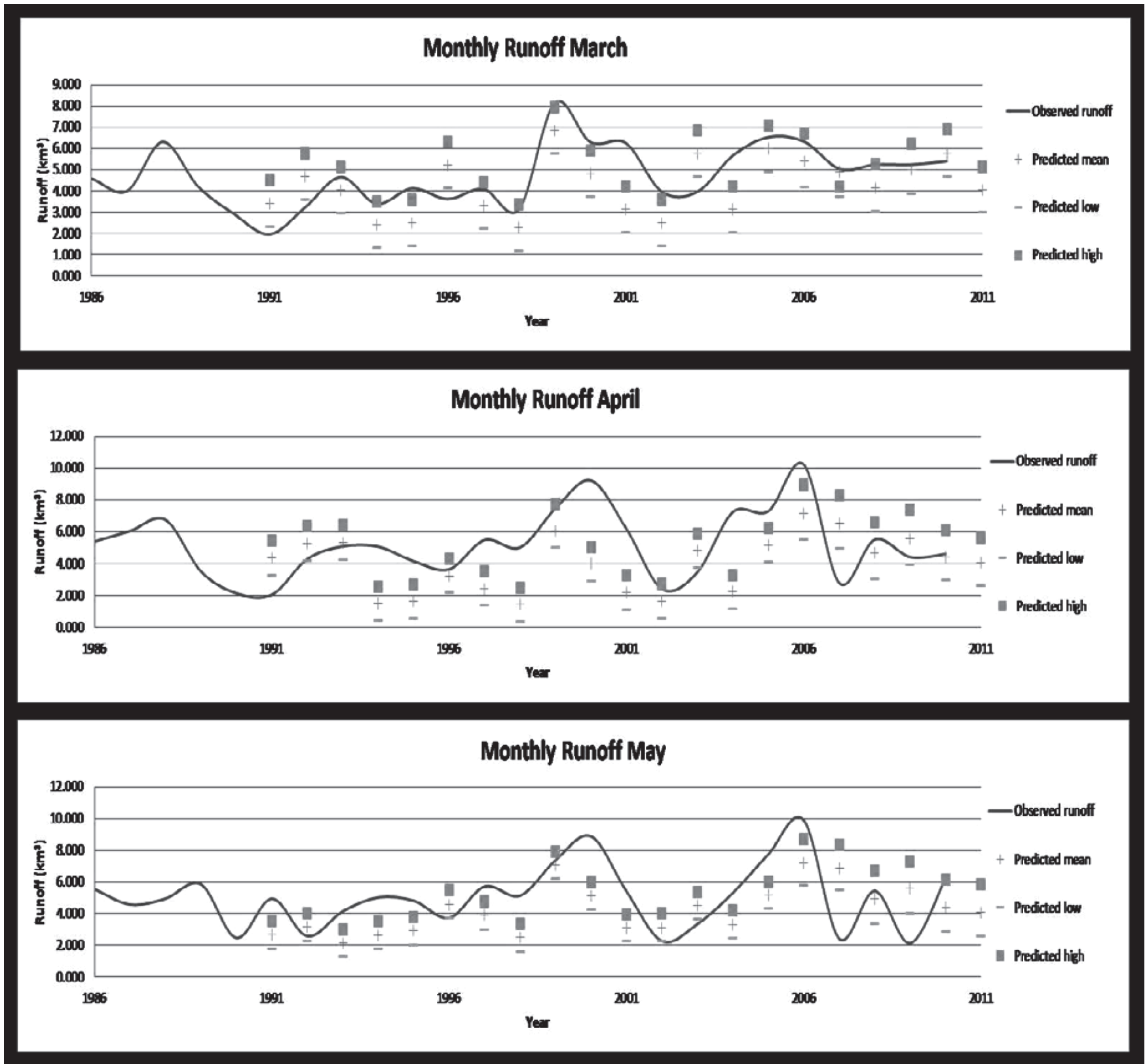

Fig. 4 Predicted and observed monthly runoff for the Tisza at Szeged. 


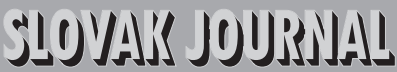 \\ 1) 5

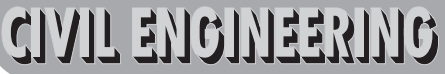

Vol. XXI, 2013, No. 3, $43-56$

water levels at the two key stations on the Danube and Tisza. The observed and predicted values are shown in Figures 5-6.

The monthly maximum water levels for Tisza at the Szeged station were predicted relatively well in March; most of the estimates remained within the predicted range. Some predictive skill was also shown for April and May (Fig.5).

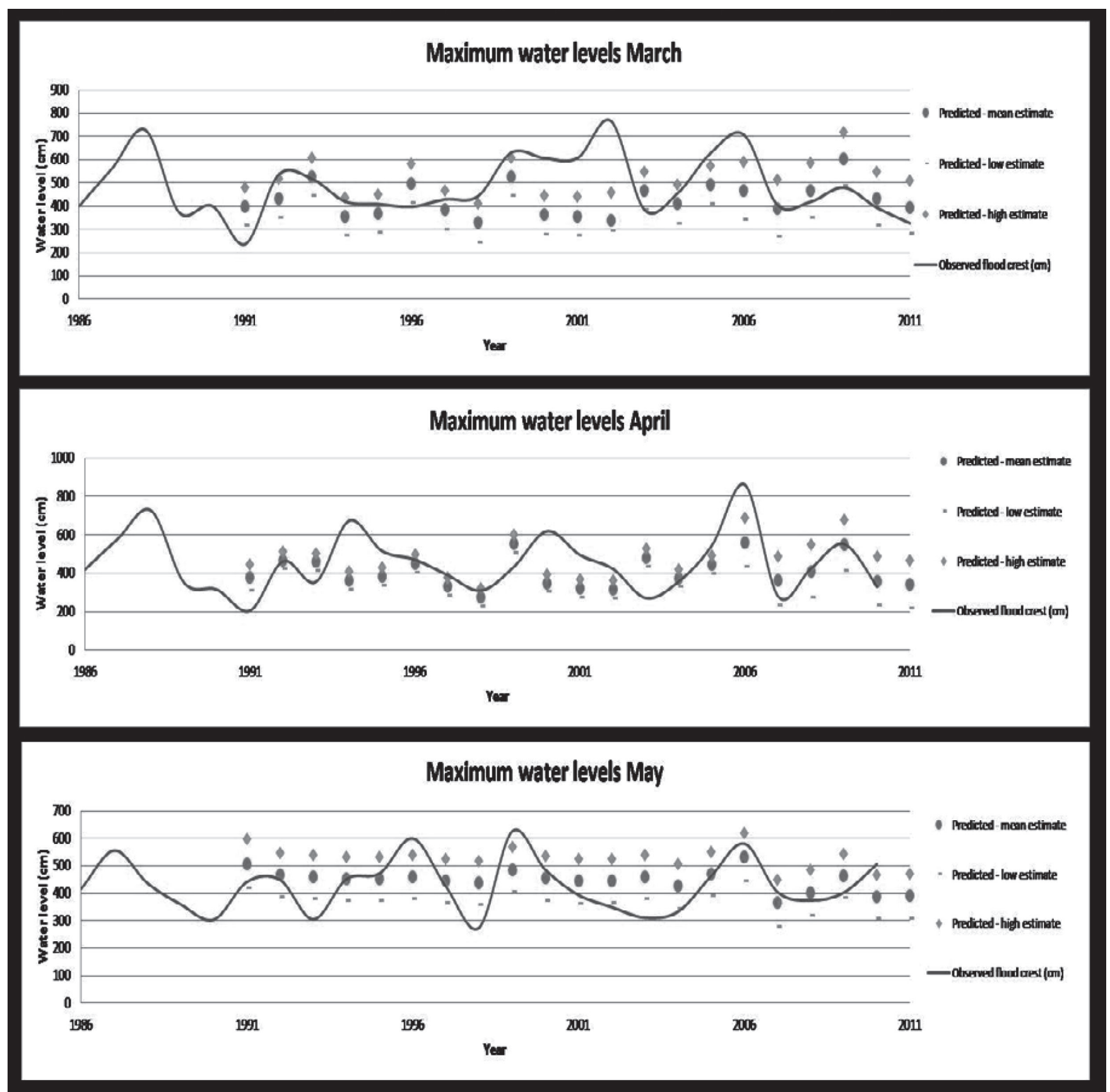

Fig. 5 Predicted and observed monthly maximum water levels for the Danube at Budapest. 


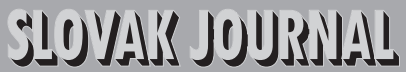 \\ 1) $\vec{s}$

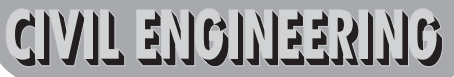

Vol. XXI, 2013, No. 3, $43-56$

A comparison of the predicted and observed monthly maximum water levels and flood crests indicated a very large scatter (Fig.7). March estimates for the Tisza River at Szeged provided some positive results. Little sign of that can be seen for April at the same station. The Danube predictions failed in most cases together with the May estimates for the Tisza.

The results received demonstrate the importance of meteorological predictions. In most cases intensive rainfall during snow events

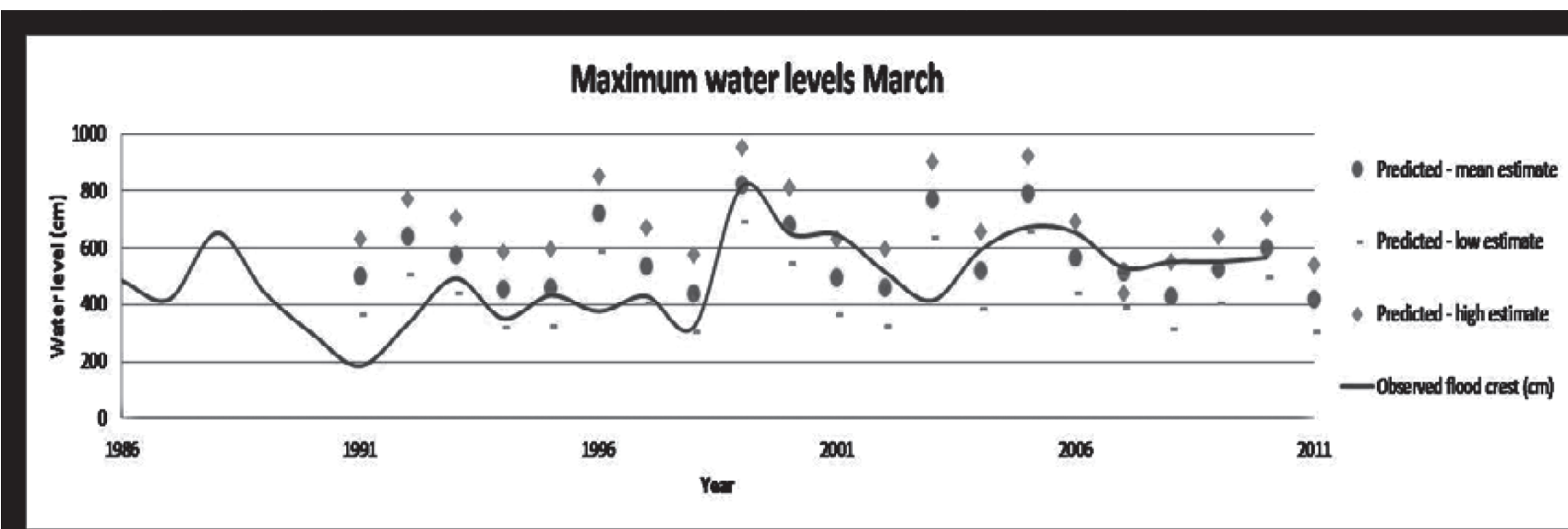

\section{Maximum water levels April}

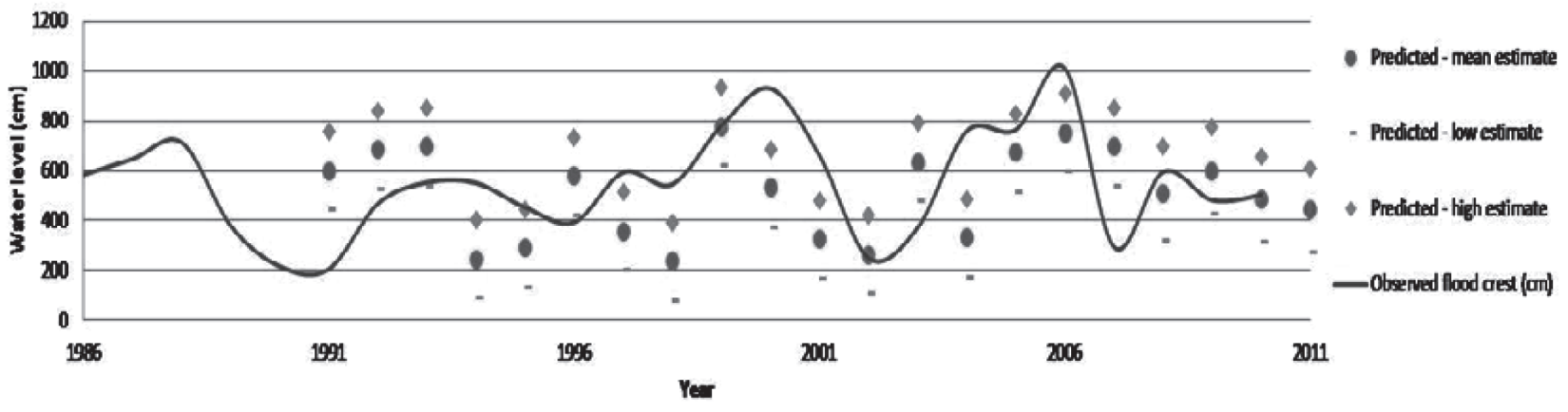

\section{Maximum water levels May}

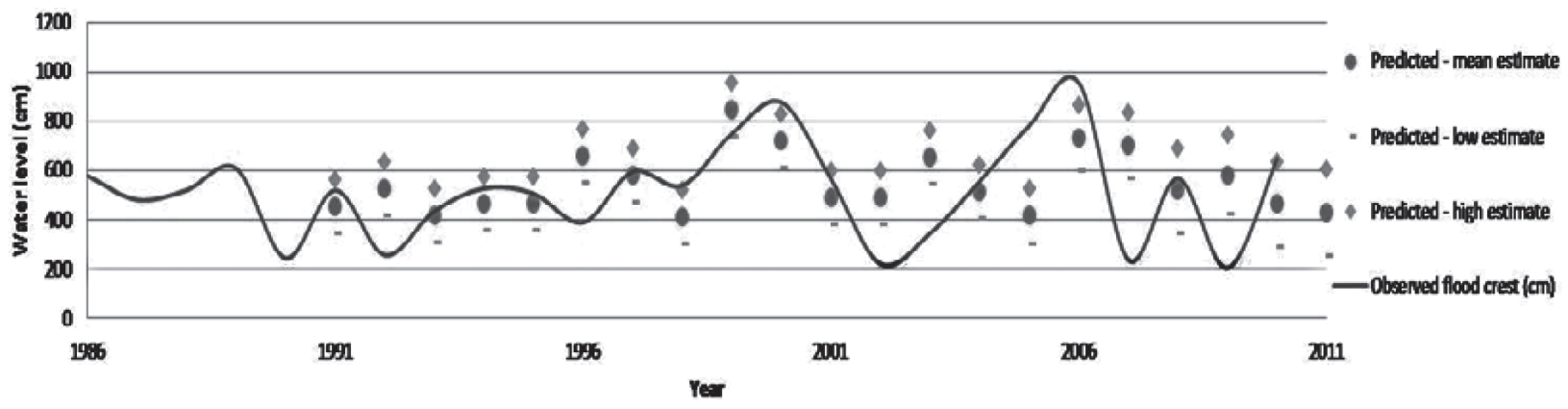

Fig. 6 Predicted and observed monthly maximum water levels for the Tisza at Szeged. 


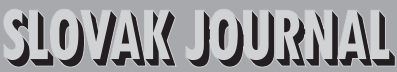 \\ 1) 5

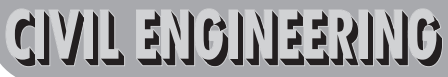

Vol. XXI, 2013, No. 3, $43-56$

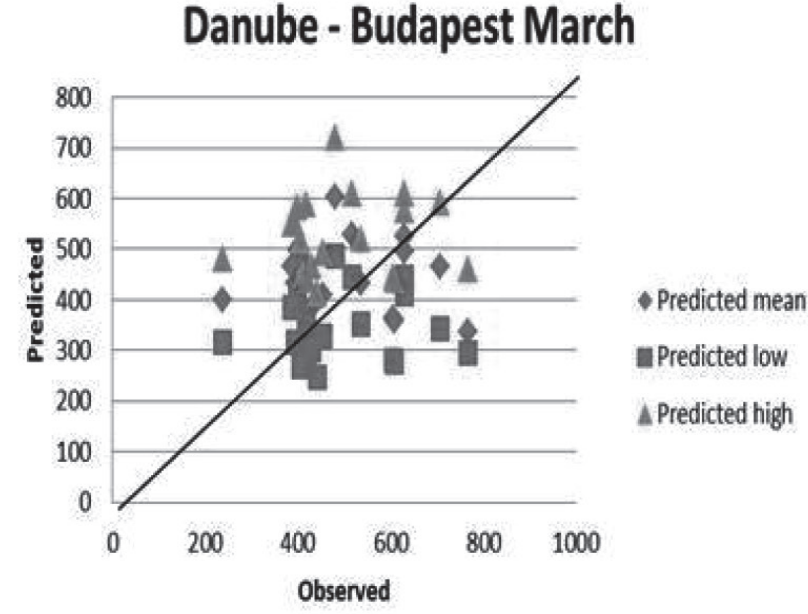

Danube - Budapest May

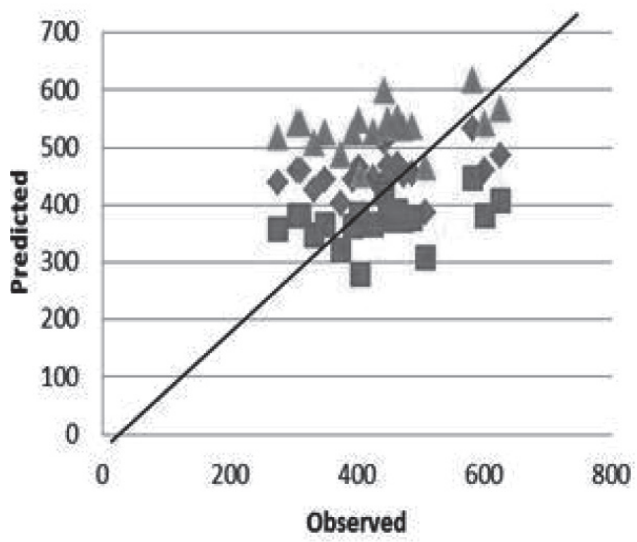

Tisza - Szeged April

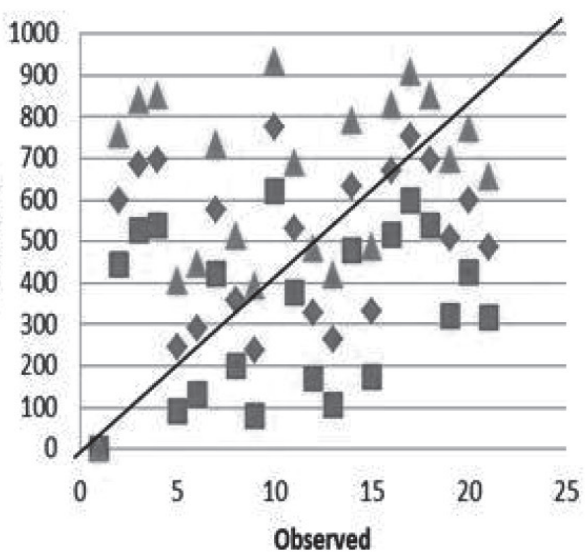

$\leftrightarrow$ Predicted mean aredicted low A Predicted high

- Predicted mean - Predicted low $\triangle$ Predicted high

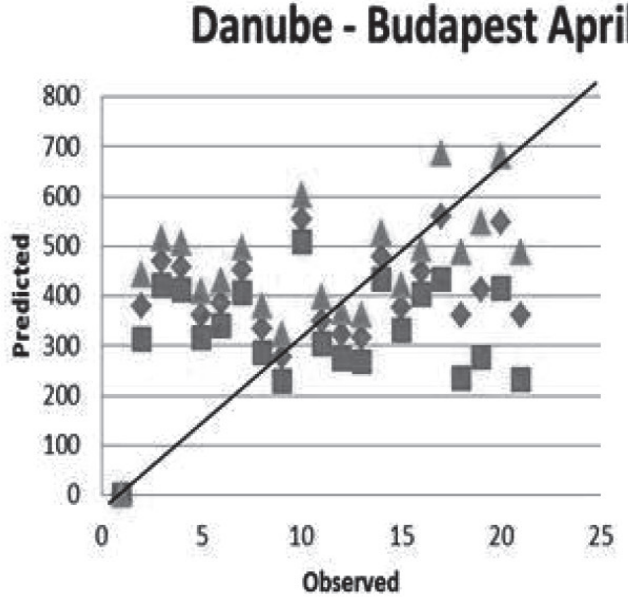

Tisza - Szeged March

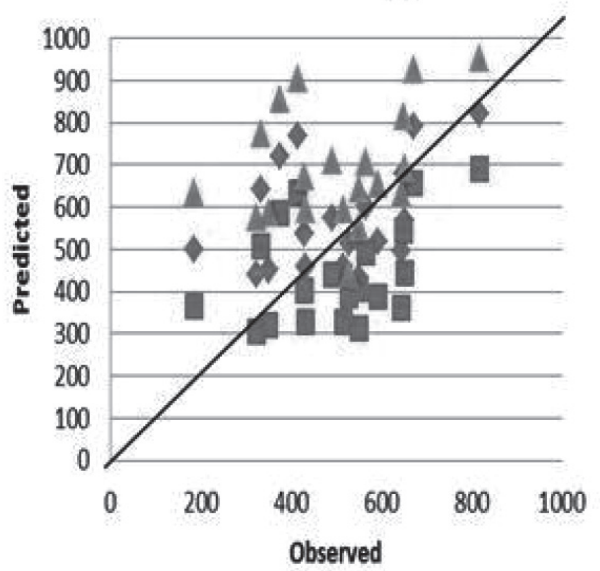

Tisza - Szeged May

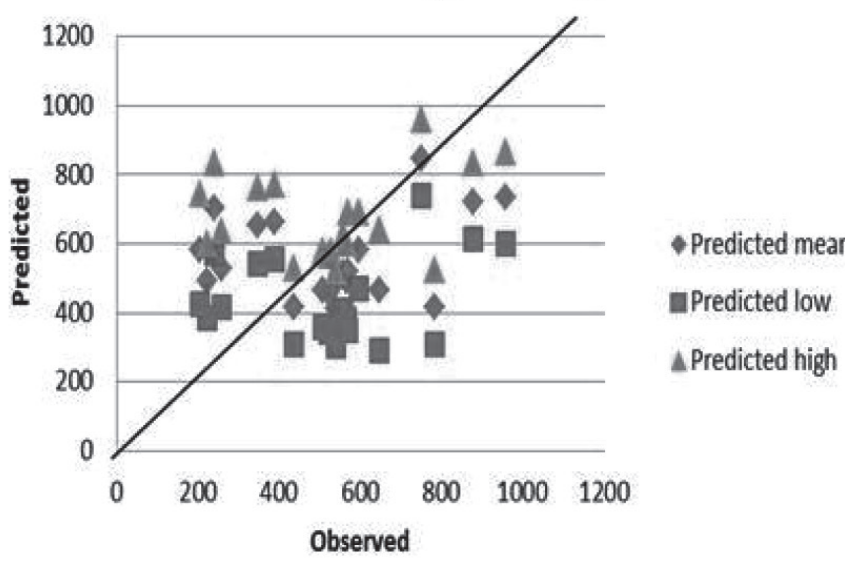

Fig. 7 Comparison of predicted and observed monthly maximum water levels. 


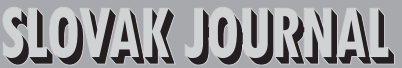 \\ 1) 5

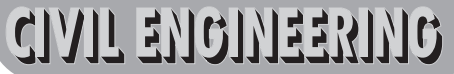

Vol. XXI, 2013, No. 3, $43-56$

trigger high floods, which are not captured by the monthly values. The new resources base prediction of the spring flow has limited value for flood early warning purposes. Slow and continuous snow melt may consume extreme snow resources while water levels remain at critical stages, and no inundation occurs.

\section{CONCLUSIONS}

The HOLV snowmelt model developed by the Hungarian National Hydrological Forecasting Service (VITUKI OVSZ/NHFS) proved to be an easily applicable tool to estimate regional snow resources for the Danube Basin. The distributed newly developed version, which covers a grid with a 0.1 degree of resolution, is in use to assess snow accumulation and ablation. The snowmelt model has a flexible structure; it is able to change its own structure as a function of the availability of the data. The quality of the snow - related process calculations (such as snow accumulation, snow melting) might be improved by the application of satellite images. However, after a detailed investigation, it becomes obvious that the development of a universally applied correction method based on satellite information meets serious difficulties. Seasonal forecasts based on the relationship between early spring snow resources and expected precipitation during spring months have been analysed for the Danube and Tisza rivers. A comparison of the predicted and observed monthly maximum water levels and flood crests indicated a very large scatter. March estimates for the Tisza River at Szeged gave some positive results. Little sign of that can be seen for April at the same station. The Danube predictions fail in most cases together with the May estimates for the Tisza. The results received demonstrate the importance of meteorological predictions. In most cases intensive rainfall during snow events triggers high floods, which are not captured by the monthly values. The new resources base prediction of the spring flow has limited value for flood early warning purposes. Slow and continuous snow melt may consume extreme snow resources while water levels remain at critical stages, and no inundation occurs. The rapid development of medium-range meteorological forecasting, especially the application of ensemble forecasts, gives hope that a complete chain of advisory, seasonal prediction, early warning, medium range and short time forecasting of floods during periods when the snowmelt component contribution is high will be designed. Snow resource - based scenario simulations can also be useful to find the 'worst case' scenarios and make it possible to operate flood regulation reservoirs or other water supply reservoirs with designated flood reduction storage volumes.

\section{Acknowledgement}

The research presented in this paper was also supported by the Slovak Agency for Science and Development under number APVV $-0015-10$. This support is gratefully acknowledged. 


\section{REFERENCES}

Bálint, G. - Gauzer, B. (1994) A rainfall runoff model as a tool to investigate the impact of climate change. In: Proceedings, XVIIth Conference of Danube Countries, Budapest, 5-9 Sept. 1994, Paper No. 3.3, 471-479.

Bálin,t G. - Harkányi, K. (1997) Extreme rainfall caused flooding study. (Szélsőséges csapadék okozta árvízek vizsgálata). Vízügyi Közlemények, LXXIX./4.

Bálint, G. - Dobi, I. - Mika, J. (1996) Runoff simulation as- suming global warming scenarios. In: 18th (XVIII) Confer- ence of the Danube Countries on Hydrological Forecasting and Hydrological Bases of Water Management, Schriftenreihe zur Wasserwirtschaft, Vol. 19/1, Technische Universität Graz, Graz - Austria, August 1996.

Bálint, G. - Bartha, P. (1982) Large-scale assessment of snow resources for forecasting spring flow. In: Hydrological Aspects of Alpine and High Mountain Areas. IAHS Publ., No. 138, Wallingford.

Bálint, G. - Csík, A. - Bartha, P. - Gauzer, B. (2005) Application of meteorological ensembles for Danube flood forecasting and warning. NATO Advanced Research Workshop, Transboundary Floods: Reducing Risks and Enhancing Security Through Improved Flood Management Planning, Oradea (Baile Felix), Romania, 4-8 May 2005. In: NATO Elsevier Transboundary Floods: Reducing Risks and Enhancing Security Through Improved Flood Management Planning, Eds. J. Marsalek, G. Stancalie, G.Bálint.

Bálint, G. - Gauzer, B. (1994) A rainfall runoff model as a tool to investigate the impact of climate change. XVIIth Conference of the Danube Countries on Hydrological Forecasting and Hydrological Bases of Water Management, Budapest, 5-9 September, 1994.

Clark, M. et al. (2009) Simulations of seasonal snow for the South Island. New Zealand Journal of Hydrology (NZ) 48 (2): 41-58 2009, New Zealand Hydrological Society.

Cyberski, J. - Grześ, M. - Gutry-Korycka, M. - Nachlik, E. Kundzewicz, Z.W. (2006) History of floods on the River Vistula. Hydrological Sciences Journal, Vol. 51, No. 5, pp. 799817, ISSN: 0262-6667.

Gauzer, B. - Bartha, P. (2001) Flood simulation studies between the river Tisza and Szeged Tokaj. (Árvízi szimulációs vizsgálatok a Tisza Tokaj-Szeged közötti szakaszán). Vízügyi Közlemények, LXXXIII/4, pp. 512-537.
Gupta, H.V. - Sorooshian, S. - Yapo, P.O. (1998) Towards Improved Calibration of Hydrologic Models: Multiple and NonCommen- surable Measures of Information. Water Resources Research, Vol. 34, No. 4, pp. 751-763.

HANDBOOK OF SNOW (1981) Principles, Processes, Management \& Use. Edited by D.M. GRAY and D.H. MALE. Toronto: Pergamon Press, 1981. 776 pp.

INSTITUTE OF HYDROLOGY (1999) Flood estimation handbook. Wallingford. UK.

Klein, A.G. - Barnett, A.C. (2003) Validation of daily MODIS snow cover maps of the Upper Rio Grande River Basin for the 2000-2001 snow year. Remote Sens. Environ., 86, 162-176.

Maurer, E.P. - Rhoads, J.D. - Dubayah, R.O. - Lettenmaier, D.P. (2003) Evaluation of the snow-covered area data product from MODIS. Hydrol. Processes, 17, 59-71.

MODIS REPROJECTION TOOL (MRT) (2004) Users guide. Release 3.2a. Department of Mathematics and Computer Science, South Dakota School of Mines and Technology, USGS EROS Data Center, 58 pp.

Mu, Q. - Zhao, M. - Running, Sw. (2011) Improvements to a MODIS global terrestrial evapotranspiration algorithm. Remote Sens Environ 115:1781-1800.

Parajka, J. - Holko, L. - Kostka, Z. - Blöschl, G. (2012) $M O D I S$ snow cover mapping accuracy in a small mountain catchmentcomparison between open and forest sites. Hydrol. Earth Syst. Sci., 16, 2365-2377.

Parajka, J. - Blöschl, G. (2006) Validation of MODIS snow cover images over Austria. Hydrol. Earth Syst. Sci., 10, 679-689.

Riggs, G.A. - Hall, D.K. - Salomonson, V.V. (2003) MODIS snow products user guide for collection 4 data products. http://modis- snow-ice.gsfc.nasa.gov/sug main.html, January 2003.

Riggs, G. - Hall, D. (2002) Reduction of cloud obscuration in the MODIS snow data product. Presented at the 59th Eastern Snow Conference, Stowe, Vermont, USA, June 2002, http://modissnow-ice.gsfc.nasa.gov/pap cloud obs02.pdf, 8 pp.

Rodell, M. - Houser, P.R. (2004) Updating a land surface model with MODIS-derived snow cover. J. Hydrometeorol., 5, 10641075 . 


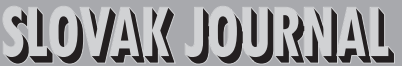 \\ 1)

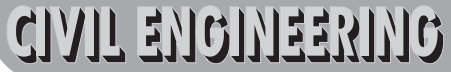

Vol. XXI, 2013, No. 3, $43-56$

Vajja, H.P. - Partha, S.R. (2005) Estimation of Snowmelt Runoff in Beas Basin. India Geocarto International, Vol. 20, No. 2, June 2005 Geocarto International Centre, Hong Kong. pp. 41-47.
Yapo, P.O. - Gupta, H.V. - Sorooshian, S. (1998) Multi-Ob- jective Global Optimization for Hydrologic Models. Journal of Hydrology, pp. 204, 83-97. 